\title{
INTERNATIONAL PORTFOLIO DIVERSIFICATION AND GENETIC RELATEDNESS
}

\author{
Cristina HARIN ${ }^{\text {a* }}$ \\ a) Babeș-Bolyai University, Faculty of Economics and Business Administration, \\ Cluj-Napoca, Romania
}

Please cite this article as:

Article History:

Harin, C., 2021. International portfolio diversification and genetic relatedness. Review of Economic Studies and Research Virgil Madgearu, 14(2), pp.15-44.

doi: 10.24193/RVM.2021.14.78.

Abstract: The purpose of this paper is to shed some light on how relatedness
between counterparties can explain investment behavior, specifically how much
can investor's inherited traits influence the exchange of capital. We use the genetic
distance index and regress it against the foreign bias measure on pairs from 40
countries on a time period from 2001-2016. We identify that the prior exerts a
significantimpactonforeigninvestmentdecision, evenwhencontrollingforprevious
documented determinants of foreign bias. These findings reflect that international
portfolio allocation is obstructed by the cultural wedge created between source and
destination country, since relative difference in these characteristics disturb the
flow of equity investments across markets, which ultimately hinder diversification.
Key words: foreign bias; genetic distance; foreign equity portfolio allocations;
cultural dimensions
JEL Classification: G11; G15; Z13

(C) 2021 Alma Mater Publishing House. All rights reserved.

* Corresponding author. E-mail address: cristina.negru@econ.ubbcluj.ro. 
Review of Economic Studies and Research Virgil Madgearu, 2021, 14(2)

\section{References:}

1. Anderson, C.W., Fedenia, M., Hirschey, M. and Skiba, H., 2011. Cultural influences on home bias and international diversification by institutional investors. Journal of Banking and Finance, 35(4), pp.916-934. https://doi.org/10.1016/j.jbankfin.2010.09.006.

2. Ang, J.B. and Kumar, S., 2014. Financial development and barriers to the cross-border diffusion of financial innovation. Journal of Banking and Finance, 39, pp.43-56. https://doi.org/10.1016/j. jbankfin.2013.10.011.

3. Ang, J.B., 2019. Culture, legal origins, and financial development. Economic Inquiry, 57(2), pp.1016-1037. https://doi.org/10.1111/ ecin.1275.

4. Bekaert, G. and Wang, X., 2009. Home bias revisited. Working paper, Columbia Business School.

5. Beugelsdijk, S. and Frijns, B., 2010. A cultural explanation of the foreign bias in international asset allocation. Journal of Banking and Finance, 34(9), pp.2121-2131. https://doi.org/10.1016/j. jbankfin.2010.01.020.

6. Beugelsdijk, S., Kostova, T. and Roth, K., 2017. An overview of Hofstede-inspired country-level culture research in international business since 2006. Journal of International Business Studies, 48(1), pp. 30-47. https://doi.org/10.1057/s41267-016-0038-8.

7. Buchanan, B., Le, Q.V. and Rishi, M., 2012. Foreign direct investment and institutional quality: Some empirical evidence. International Review of Financial Analysis, 21(C), pp. 81-89. https://doi. org/10.1016/j.irfa.2011.10.001.

8. Cavalli-Sforza, L.L., Menozzi, P. and Piazza, A., 1994. The History and Geography of Human Genes. Princeton: Princeton University Press.

9. Chan, K., Covrig, V. and Ng, L., 2005. What determines the domestic bias and foreign bias? Evidence from mutual fund equity allocations worldwide. Journal of Finance, 6o, pp.1495-1534. https://doi. org/10.1111/j.1540-6261.2005.768_1.x.

10. Chew, S.H., Ebstein, R.P. and Zhong, S., 2012. Ambiguity aversion and familiarity bias: Evidence from behavioral and gene association studies. Journal of Risk and Uncertainty, 44(1), pp. 1-18. https:// doi.org/10.1007/s11166-011-9134-0. 
11. Cronqvist, H. and Siegel, S., 2014. The genetics of investment biases. Journal of Financial Economics, 113(2), pp.215-234. https://doi. org/10.1016/j.jfineco.2014.04.004.

12. Dahlquist, M., Pinkowitz, L., Stulz, R. and Williamson, R., 2003. Corporate governance and the home bias. Journal of Financial Quantitative Analysis, 38, pp.87-110. https://doi. org/10.2307/4126765.

13. De Santis, G. and Gerard, B., 1997. International Asset Pricing and Portfolio Diversification with Time-Varying Risk. The Journal of Finance, 52(5), pp. 1881-1912. https://doi.org/10.2307/2329468.

14. French, K.R. and Poterba, J.M., 1991. Investor Diversification and International Equity Markets. The American Economic Review, 81(2), pp.222-226. https://doi.org/10.3386/w3609.

15. Hofstede, G. 2001. Culture's consequences: Comparing values, behaviors, institutions, and organizations across nations. Thousand Oaks, CA: Sage.

16. Giannetti, M. and Koskinen, Y., 2010. Investor protection, equity returns and financial globalization. Journal of Financial Quantitative Analysis, 45, pp.135-168. https://doi.org/10.1017/ So022109009990524.

17. Gintis, H., 2010. Social norms as choreography. Politics, Philosophy and Economics, 9(3), pp.251-264. https://doi. org/10.1177/1470594Xo9345474.

18. Giofre, M., 2017. Financial Education, investor protection and international portfolio diversification. Journal of International Money and Finance, 71(C), pp.111-139. https://doi.org/10.1016/j. jimonfin.2016.11.004.

19. Guiso, L., Sapienza, P. and Zingales, L., 2009. Cultural biases in economic exchange? Quarterly Journal of Economics, 124(3), pp.1095-1131. https://doi.org/10.1162/qjec.2009.124.3.1095.

20. Kirkman, B.L., Lowe, K.B. and Gibson, C., 2006. A quarter century of Culture's Consequences: A review of the empirical research incorporating Hofstede's cultural value framework. Journal of International Business Studies, 36(3), pp.285-320. https://doi. org/10.1057/palgrave.jibs.8400202.

21. Kwok, C. and Reeb, D., 2000. Internationalization and Firm Risk: An Upstream-Downstream Hypothesis. Journal of International Business Studies, 31(4), pp.611-629. 
22. Mishra, A.V., 2015. Measures of Equity Home Bias Puzzle. Journal of Empirical Finance, 34, pp.293-312. https://doi.org/10.1016/j. jempfin.2015.08.001.

23. Porta, R.L., Lopez de Silanes, F., Shleifer, A. and Vishny, R.W., 1998. Law and Finance. Journal of Political Economy, 106(6), pp.1113-1155.

24. Spolaore, E. and Wacziarg, R., 2009. The diffusion of development. Quarterly Journal of Economics, 124(2), pp. 469-529. https://doi. org/10.1162/qjec.2009.124.2.469.

25. Spolaore, E. and Wacziarg, R., 2016. Ancestry, Language and Culture. In: V. Ginsburgh and S. Weber, eds. The Palgrave Handbook of Economics and Language. London: Palgrave Macmillan. https:// doi.org/10.1007/978-1-137-32505-1_7.

26. Wang, W., Su, C. and Duxbury, D., 2021. Investor sentiment and stock returns: Global evidence. Journal of Empirical Finance, 63, pp. 365-391. https://doi.org/10.1016/j.jempfin.2021.07.010. 